\title{
The Presence of Compounds from the Personal Care Products Group in Swimming Pool Water
}

\author{
Anna Lempart ${ }^{1 *}$, Edyta Kudlek', Marta Lempart ${ }^{1}$, Mariusz Dudziak ${ }^{1}$ \\ 1 Silesian University of Technology, Institute of Water and Wastewater Engineering, Konarskiego 18, \\ 44-100 Gliwice, Poland \\ * Corresponding author's e-mail: anna.lempart@polsl.pl
}

\begin{abstract}
The global production of several thousands of Personal Care Products (PCPs) every year makes the release of PCPs to the environment an unavoidable by-product of a modernized lifestyle. Multiple studies have detected PCPs worldwide in various aquatic environments, including swimming pools. In the presented work, the concentrations of three selected compounds from the PCPs group were examined in 15 swimming pools with different functions. The aim of the study was to show the influence of various factors on the concentration levels of selected micropollutants. Two UV filters: BP-3 (oxybenzone), BP-8 (dioxybenzone) and one antioxidant BTH (dibutylhydroxytoluene) were selected for the research. The extraction of micropollutants from the swimming pool water matrix was carried out by Solid Phase Extraction (SPE). The extracts were analyzed using a gas chromatograph (GC) coupled to the mass detector (MS). BHT was the most common compound. Its concentration ranged from $3.8 \mathrm{ng} / \mathrm{L}$ to $5.5 \mathrm{ng} / \mathrm{L}$. The most rarely occurring compound was BP-3. The concentration of this compound varied the most, from $18.5 \mathrm{ng} / \mathrm{L}$ to $1178.6 \mathrm{ng} / \mathrm{L}$. BP-8 was present in 10 from 15 tested pools at the concentration level of 49.9-226.9 ng/L. The frequency of occurrence characterizing different micropollutants from PCPs group was higher in recreational pools than in sports pools. It was also observed that the applied water treatment technology may affect the presence of Personal Care Products in the swimming pool water. No impact of basic water quality parameters on the levels of tested pharmaceuticals has been shown in this research.
\end{abstract}

Keywords: swimming pools, personal care products, cosmetics, micropollutants, parabens, UV filters

\section{INTRODUCTION}

The group of Personal Care Products (PCPs) includes the compounds present in both personal hygienic items, which are necessities, and cosmetics, which are luxury goods solely used for beautification. It concerns products as diverse as for example colognes, deodorants, eye liners, lip glosses, lipsticks, lotions, nail polishes, pomades, perfumes, shaving cream, moisturizers, talcum powders, toothpastes, sunscreens, soaps, fragrances, insect repellents, and shampoos. The personal-care industry is a massive field. According to the Personal Care Products Council, a trade association for the cosmetics and personal-care products industry that has more than $600 \mathrm{mem}$ ber companies, it generates more than $\$ 250$ billion in annual retail sales, worldwide. The global production of several thousands of PCPs every year makes the release of PCPs to the environment an unavoidable by-product of a modernized lifestyle.

Multiple studies have detected PCPs worldwide in various aquatic environments such as surface waters, groundwater, drinking waters [Boyd et al. 2003; Cizmas et al. 2015; Ebele et al. 2017, Snyder et al. 2004; Yang et al. 2017] and more recently, swimming pool waters [Cuderman and Heath 2007; Ekowati et al. 2016; Giokas et al. 2004; Giokas et al. 2005; Lambropoulou et al. 2002; Lempart et al. 2017; Lopez-Darias et al. 2010; Regueiro et al. 2009; Suppes et al. 2017; Terasaki and Makino 2008; Vidal et al. 2010; Li et al. 2015; Zwiener et al. 2007]. Some compounds from the PCPs group may cause negative human health effects, mainly the allergic reactions, but also the endocrine or fertility disorders [Caliman and Gavrilescu 2009; Piao et al. 2014, Tavares et 
al. 2009] and hormonal changes [Golden et al. 2005; Kunz et al., 2006; Kunz and Fent 2006; Ma et al., 2003; Morohoshi et al. 2005; Schlumpf et al. 2001; Suzuki et al. 2005]. For this reason, their presence in swimming pools, where users are directly exposed to them by three different routes: inhalation, absorption through the skin and ingestion, seems to be particularly worrying. Swimming is a popular leisure activity that can provide health benefits for the public. However, it turns out that the exposure to water in swimming pools may cause a number of health risks related to the chemical hazards caused i.a. by PCPs and the occurrence of their by-products. The PCPs of concern in swimming pool water include compounds with the ability to absorb UV radiation, which are the main component of sunscreen products and parabens that are widely applied as antimicrobial preservatives in cosmetics, pharmaceuticals and food, as well as active substances in antiperspirants and antidandruff products. The Personal Care Products detected so far in swimming pools are summarized in Table 1.

UV filters are the main components of sunscreens. They are composed of organic and inorganic compounds which absorb or reflect the UV light. Due to the mechanism of action, they can be divided into two basic groups: physical filters and chemical filters. The physical filters include titanium dioxide $\left(\mathrm{TiO}_{2}\right)$ and zinc oxide $(\mathrm{ZnO})$. Their action is based on the scattering of radiation [Bojnarowicz and Bartnikowska 2014]. The chemical filters are organic compounds that have the ability to absorb the radiation. The common feature all of them is the presence of numerous unsaturated bonds and moieties containing free electron pairs in the molecule. They absorb the energy of sunlight, turning it into the thermal energy. They commonly consist of aromatic compounds conjugated with carbonyl groups. The most commonly used are benzophenones, phenylbenzotriazoles and the derivatives of: p-aminobenzoic acid, $p$ methoxycinnamonic acid, salicylic acid, camphor, dibenzoylmethane and benzylidenecamphor [Bojnarowicz and Bartnikowska 2014]. Some sunscreen agents exhibit estrogenicity and antiandrogenicity [Kunz et al., 2006, Kunz and Fent, 2006; Ma et al., 2003; Morohoshi et al., 2005; Schlumpf et al., 2001; Suzuki et al., 2005]. There are also concerns about their potential carcinogenicity [Lowe 2006]. Certain sunscreen agents in aquatic matrices are degraded under the influence of sunlight and reaction with chlorine [Nakajima et al. 2009; Negreira et al. 2008; Rodil et al. 2009,
Sakkas et al. 2003; Serpone et al. 2002; Virkutyte et al. 2012]. These transformations can cause the formation of by-products that may be more harmful than their parent compounds. [Díaz-Cruz and Barceló 2009; Giokas et al. 2007].

Parabens, a group of alkyl esters of p-hydroxybenzoic acid (PHBA), in general are moderately soluble in water and not volatile. Due to the active phenol hydroxyl groups, they can be easily transformed to mono- and di-chlorinated derivatives in chlorinated water [Terasaki et al. 2012; Westerhoff et al. 2005]. Therefore, during the disinfection of swimming pool water, they may form chlorinated parabens which are more stable in environment and more toxic than the corresponding parent parabens [Bledzka et al. 2014; Terasaki et al. 2009]. Both parabens and their chlorinated derivatives exhibit the endocrine-disrupting properties. They can modulate or disrupt the endocrine system and harm human health [Golden et al. 2005, Piao et al. 2014]. The association between the human exposure to parabens and adverse health outcomes has been shown in the epidemiological studies [Meeker et al. 2011; Savage et al. 2012]. PHBAs, due to their common presence in Personal Care Products, are the most sensitizing substances in contact.

In the presented work, the concentrations of three selected compounds from the PCPs group were examined in swimming pools with different functions. Two UV filters, BP-3 (oxybenzone), BP-8 (dioxybenzone) and one antioxidant BTH (dibutylhydroxytoluene) were selected for research. They are characterized in Table 2.

The aim of the study was to show the influence of various factors on the concentration levels of selected micropollutants.

\section{MATERIALS AND METHODS}

The PCPs listed in Table 2 are the target compounds in this study. The standards of high purity (BP-3 and BP- $8>98 \%$, BHT $>95 \%$ ) were purchased from Sigma Aldrich. The cartridges used for Solid Phase Extraction were Supelclean ${ }^{\mathrm{TM}}$ ENVI-18 SPE Tube from Sigma Aldrich filled with non-polar adsorbent C18 (octadecyl bonding). Organic solvents: methanol and acetonitrile of purity grade $>99.8 \%$ and $>99.5 \%$, respectively, by Avantor Performance Materials Poland S.A. were also applied to Solid Phase Extraction. A gas chromatograph coupled with a mass detector (GC-MS) with electron ionization (EI) by PER- 
Table 1. Concentration levels of PCPs in swimming pool water

\begin{tabular}{|c|c|c|c|c|}
\hline Application & Compound & Content [ng/L] & Country & References \\
\hline \multirow{11}{*}{ UV filters } & BP-1 & $<0.1-1.2$ & Spain & [Ekowati et al. 2016] \\
\hline & BP-2 & $<0.1-27.2$ & Spain & [Ekowati et al. 2016] \\
\hline & BP-3 & $\begin{array}{l}2400-3300 \\
4.2-5.7 \\
6.5-8.2 \\
103-400 \\
1200 \\
<110 \\
<0.1-15.5 \\
\text { not tested }\end{array}$ & $\begin{array}{l}\text { Greece } \\
\text { Greece } \\
\text { Greece } \\
\text { Slovenia } \\
\text { Germany } \\
\text { Spain } \\
\text { Spain }\end{array}$ & $\begin{array}{l}\text { [Lambropoulou et al. 2002] } \\
\text { [Giokas et al. 2004] } \\
\text { [Giokas et al.2005] } \\
\text { [Cuderman and Heath 2007] } \\
\text { [Zwiener et al. 2007] } \\
\text { [Vidal et al. 2010] } \\
\text { [Ekowati et al. 2016] } \\
\text { [Suppes et al. 2017] }\end{array}$ \\
\hline & BP-8 & $<0.1-21.6$ & Spain & [Ekowati et al. 2016) \\
\hline & $4 \mathrm{MBC}$ & $\begin{array}{c}5.4-6.9 \\
13-20 \\
<146-330 \\
1.4-10 \\
<60-200 \\
<0.1-69.3\end{array}$ & $\begin{array}{l}\text { Greece } \\
\text { Greece } \\
\text { Slovenia } \\
\text { Germany } \\
\text { Spain } \\
\text { Spain }\end{array}$ & $\begin{array}{l}\text { [Giokas et al. 2004] } \\
\text { [Giokas et al.2005] } \\
\text { [Cuderman and Heath 2007] } \\
\text { [Zwiener et al. 2007] } \\
\text { [Vidal et al. 2010] } \\
\text { [Ekowati et al. 2016] }\end{array}$ \\
\hline & OD-PABA & $\begin{array}{l}<900-2100 \\
\quad<37 \\
<70 \\
<0.1-2.0\end{array}$ & $\begin{array}{l}\text { Greece } \\
\text { Slovenia } \\
\text { Spain } \\
\text { Spain }\end{array}$ & $\begin{array}{l}\text { [Lambropoulou et al. 2002] } \\
\text { [Cuderman and Heath 2007] } \\
\text { [Vidal et al. 2010] } \\
\text { [Ekowati et al. 2016] }\end{array}$ \\
\hline & $\mathrm{OMC}$ & $\begin{array}{l}3-4.5 \\
7.4-11 \\
2.7-7\end{array}$ & $\begin{array}{l}\text { Greece } \\
\text { Greece } \\
\text { Germany }\end{array}$ & $\begin{array}{l}\text { [Giokas et al. 2004] } \\
\text { [Giokas at al.2005] } \\
\text { [Zwiener et al. 2007] }\end{array}$ \\
\hline & 1HBT & $<0.1-18.8$ & Spain & [Ekowati et al. 2016] \\
\hline & 4DHB & $<0.1-30.8$ & Spain & [Ekowati et al. 2016] \\
\hline & MeBT & $<0.1-3.4$ & Spain & [Ekowati et al. 2016] \\
\hline & DMeBT & $<0.1-3.1$ & Spain & [Ekowati et al. 2016] \\
\hline \multirow{13}{*}{ Parabens } & $\mathrm{BzP}$ & $\begin{array}{c}28 \\
6.25 \\
\end{array}$ & $\begin{array}{l}\text { Japan } \\
\text { China }\end{array}$ & $\begin{array}{l}\text { [Terasaki and Makino 2008] } \\
\text { [Li et al. 2015] }\end{array}$ \\
\hline & PrP & $\begin{array}{c}32 \\
266\end{array}$ & $\begin{array}{l}\text { Spain } \\
\text { China }\end{array}$ & $\begin{array}{l}\text { [Regueiro et al. 2009; } \\
\text { Lopez-Darias et al. 2010] } \\
\text { [Li et al. 2015] }\end{array}$ \\
\hline & iPrP & 25 & Japan & [Terasaki and Makino 2008] \\
\hline & BuP & $\begin{array}{c}13 \\
49.2\end{array}$ & $\begin{array}{l}\text { Spain } \\
\text { China }\end{array}$ & $\begin{array}{l}\text { [Regueiro et al. 2009; } \\
\text { Lopez-Darias et al. 2010] } \\
\text { [Li et al. 2015] }\end{array}$ \\
\hline & $\mathrm{MeP}$ & $0.16-872$ & China & [Li et al. 2015] \\
\hline & EtP & 110 & China & [Li et al. 2015] \\
\hline & $\mathrm{HeP}$ & 0.06 & China & [Li et al. 2015] \\
\hline & OcP & 0.69 & China & [Li et al. 2015] \\
\hline & 3-Cl-MeP & 7.49 & China & [Li et al. 2015] \\
\hline & 3,5-2Cl-MeP & $0.22-36.2$ & China & [Li et al. 2015] \\
\hline & 3-Cl-EtP & 0.64 & China & [Li et al. 2015] \\
\hline & 3,5-2Cl-EtP & $0,40-24.2$ & China & [Li et al. 2015] \\
\hline & PHBA & 1122 & China & [Li et al. 2015] \\
\hline
\end{tabular}

* Only the frequency of presence was analyzed.

LAN Technologies, model 7890B, was used for the chromatographic analysis.

The water samples of $100 \mathrm{~mL}$ volume were collected from eight swimming centers (B1-B8) and one hotel (B9 H) located in Poland within 6 months (June-November 2017). Swimming center B1 includes four different pools: Sports Pool (B1 S), Jacuzzi (B1 J), Paddling Pool (B1_P) and Water Slide $(B 1-W)$. Swimming centers $B 2$ B4 include Sports Pools (B2_S, B3_S, B4_S) and
Jacuzzis (B2 J, B3 J, B4 J). Each of swimming centers B5-B7 includes only one Sports Pool (B5_S, B6_S, B7_S), while B8 includes only one Paddling Pool for children to learn to swim (B8 P). In total, water samples were collected from 15 different indoor pools: 7 sports pools and 8 recreational pools (including 4 Jacuzzis, 2 paddling pools, 1 water slide pool and 1 hotel's pool). They are summarized in Table 3 . The basic physicochemical parameters $\left(\mathrm{pH}\right.$, absorbance $\mathrm{UV}_{254}$, 
Table 2. The characteristics of selected compounds

\begin{tabular}{|c|c|c|c|}
\hline & Oxybenzone (BP-3) & Dioxybenzone (BP-8) & Dibutylhydroxytoluene (BHT) \\
\hline Structural formula & & $\mathrm{OH}$ & \\
\hline Chemical formula & $\mathrm{C}_{14} \mathrm{H}_{12} \mathrm{O}_{3}$ & $\mathrm{C}_{14} \mathrm{H}_{12} \mathrm{O}_{4}$ & $\mathrm{C}_{15} \mathrm{H}_{24} \mathrm{O}$ \\
\hline CAS Number & $131-57-7$ & $131-53-3$ & $128-37-0$ \\
\hline Molar mass [g/mol] & 228.25 & 244.25 & 220.36 \\
\hline Applications & $\begin{array}{c}\text { Personal Care Products } \\
\text { / in sunscreens, hair sprays, and nail } \\
\text { polishes as an ultraviolet light absorber } \\
\text { and stabilizer/ }\end{array}$ & $\begin{array}{l}\text { Personal Care Products } \\
\text { /in sunscreen to block UVB } \\
\text { and short-wave UVA rays/ }\end{array}$ & $\begin{array}{l}\text { Personal Care Products } \\
\text { /as an antioxidant/ }\end{array}$ \\
\hline
\end{tabular}

Table 3. The characteristics of tested swimming pools and parameters of water samples

\begin{tabular}{|c|l|l|l|c|c|c|c|c|}
\hline \multirow{2}{*}{ Name } & \multirow{2}{*}{ Type } & \multicolumn{2}{|c|}{ Treatment } & \multirow{2}{*}{ pH } & \multirow{2}{*}{ UV $_{254}$} & \multirow{2}{*}{ Conductivity } & \multirow{2}{*}{ TOC } \\
\cline { 3 - 8 } & coagulation & \multicolumn{2}{|c|}{ filtration } & disinfectant & & \\
\hline B1_S & Sport pool & Yes & Multi-layer pressure filters & $\mathrm{NaOCl}$ & 7.20 & 0.032 & 1.095 & 3.82 \\
\hline B1_J & Jacuzzi & Yes & Multi-layer pressure filters & $\mathrm{NaOCl}$ & 6.83 & 0.018 & 1.2708 & 1.52 \\
\hline B1_P & Paddling pool & Yes & Multi-layer pressure filters & $\mathrm{NaOCl}$ & 7.31 & 0.027 & 0.3985 & 2.97 \\
\hline B1_W & Water slide & Yes & Multi-layer pressure filters & $\mathrm{NaOCl}$ & 7.52 & 0.030 & 1.1537 & 3.65 \\
\hline B2_S & Sport pool & Yes & Multi-layer pressure filters & $\mathrm{NaOCl}$ & 6.90 & 0.007 & 1.960 & 0.69 \\
\hline B2_J & Jacuzzi & Yes & Multi-layer pressure filters & $\mathrm{NaOCl}$ & 6.97 & 0.006 & 1.196 & 0.89 \\
\hline B3_S & Sport pool & Yes & Multi-layer pressure filters & $\mathrm{NaOCl}$ & 6.73 & 0.012 & 0.7966 & 3.49 \\
\hline B3_J & Jacuzzi & Yes & Multi-layer pressure filters & $\mathrm{NaOCl}$ & 7.00 & 0.005 & 0.9541 & 0.79 \\
\hline B4_S & Sport pool & Yes & Multi-layer pressure filters & $\mathrm{NaOCl}$ & 5.99 & 0.033 & 0.8367 & 2.99 \\
\hline B4-J & Jacuzzi & Yes & Multi-layer pressure filters & $\mathrm{NaOCl}$ & 8.23 & 0.050 & 0.6032 & 4.89 \\
\hline B5_S & Sport pool & Yes & Multi-layer pressure filters & $\mathrm{NaOCl}$ & 7.29 & 0.021 & 1.2160 & 0.83 \\
\hline B6_S & Sport pool & Yes & Multi-layer pressure filters & $\mathrm{NaOCl}$ & 6.69 & 0.126 & 0.6663 & 7.66 \\
\hline B7_S & Paddling pool & Yes & Multi-layer pressure filters & $\mathrm{NaOCl}$ & 6.99 & 0.028 & 2.169 & 9.09 \\
\hline B8_P & Paddling pool & Yes & Multi-layer pressure filters & $\mathrm{NaOCl}$ & 5.57 & 0.048 & 1.9978 & 28.07 \\
\hline B9_H & Hotel's pool & Yes & Multi-layer pressure filters & $\mathrm{NaOCl}$ & 7.33 & 0.014 & 0.4431 & 4.03 \\
\hline
\end{tabular}

conductivity, total organic carbon) of collected water samples are also shown in Table 3.

The collected water samples were subjected to the chromatographic analysis to determine the concentrations of selected micropollutants in different types of swimming pools. The chromatographic analysis and the sample preparation were carried out in accordance with the developed analytical procedure presented in the paper [Lempart et al. 2018], which enables the qualitative and quantitative analysis of micropollutants from the group of Pharmaceutical and Personal Care Products with satisfactory reproducibility and accuracy. The obtained recovery values ensure the possibility of full quantitative control of the examined micropollutants in samples collected from swimming pools.

Depending on the point of sampling, the measured concentrations of the micropollutants may be different. Therefore, the samples were collected from 7 different points of each swimming pool and then mixed together. Every representative sample prepared in this way was extracted using the SPE methodology and analyzed using the GC-MS three times in order to minimize the potential analytical mistakes. The presented in paper concentrations of compounds are the arithmetical mean of these results.

The Limits Of Quantification (LOQ) of the tested pharmaceuticals were $0.85 \mathrm{ng} / \mathrm{L}$ for BHT, $0.67 \mathrm{ng} / \mathrm{L}$ for BP-3, and $0.74 \mathrm{ng} / \mathrm{L}$ for BP-8, respectively. The values of the Coefficient of Variation $(\mathrm{CV})$ that is a measure of the repeatability of the results, do not exceed 3\% which confirms the high repeatability of the conducted measurements.

The details of the analytical procedure are presented in Table 4. 
Table 4. The details of the analytical procedure

\begin{tabular}{|c|c|c|c|c|c|}
\hline \multirow[b]{2}{*}{ Extraction conditions } & Conditioning & Washing & $\begin{array}{c}\text { Application } \\
\text { of water sample }\end{array}$ & Drying & Elution \\
\hline & $\begin{array}{l}5 \mathrm{~mL} \text { of methanol } \\
\text { and } 5 \mathrm{~mL} \text { of } \\
\text { acetonitrile }\end{array}$ & $\begin{array}{c}5 \mathrm{~mL} \text { of deionized } \\
\text { water }\end{array}$ & $\begin{array}{c}100 \mathrm{~mL} \text { with a flow } \\
\text { of } \sim 1-2 \text { drops/second; }\end{array}$ & $\begin{array}{c}5 \text { minutes under } \\
\text { vacuum }\end{array}$ & $\begin{array}{c}1.5 \mathrm{~mL} \\
\text { of acetonitrile } \\
\text { and } 1.5 \mathrm{~mL} \\
\text { of methanol }\end{array}$ \\
\hline \multirow{2}{*}{$\begin{array}{l}\text { Chromatograph } \\
\text { parameters }\end{array}$} & The column & $\begin{array}{l}\text { The support } \\
\text { phase }\end{array}$ & $\begin{array}{l}\text { The ion recording } \\
\text { mode of mass detector }\end{array}$ & \multicolumn{2}{|c|}{ The oven temperature program } \\
\hline & $\begin{array}{l}\mathrm{SLB}^{\mathrm{TM}}-5 \mathrm{~ms} \\
\text { capillary GC of } \\
\text { Supelco }\end{array}$ & $\begin{array}{l}\text { helium with } \\
\text { a flow of } \\
1.1 \mathrm{~mL} / \mathrm{min}\end{array}$ & $50-700 \mathrm{~m} / \mathrm{s}$ & \multicolumn{2}{|c|}{$\begin{array}{c}80^{\circ} \mathrm{C}(6 \mathrm{~min}), 5^{\circ} \mathrm{C} / \mathrm{min} \text { to } 260^{\circ} \mathrm{C} \\
20^{\circ} \mathrm{C} / \mathrm{min} \text { to } 300^{\circ} \mathrm{C}\end{array}$} \\
\hline
\end{tabular}

\section{RESULTS AND DISCUSSION}

The Figure 1 shows the concentrations of selected micropollutants in different types of swimming pool basins (Sports Pool, Jacuzzi, Paddling Pool and Water Slide) in one swimming center, B1. Both BHT and BP-8 were present in all types of basins in this swimming center. The concentration levels of BP-8 varied from 49.9 to $53.2 \mathrm{ng} / \mathrm{L}$, while the concentration levels of BHT ranged 4.2-5.0 ng/L. BP-3 occurred in two pools in the concentrations higher than value of Limit of Quantification, $18.5 \mathrm{ng} / \mathrm{L}$ in Paddling Pool and $51.9 \mathrm{ng} / \mathrm{L}$ in Sports Pool. In Jacuzzi and Water Slide Pool, its concentration was lower than $\mathrm{LOQ}_{\mathrm{BP}-3} 0.67 \mathrm{ng} / \mathrm{L}$.

The Figure 2 presents the concentrations of selected micropollutants in the same types of basin in different swimming pool centers. The concentration of BHT (Fig. 2 a) fluctuated slightly, in Sports Pools it changed 3.8-5.0 ng/L, in Jacuzzi it varied 4.1-4.7 $\mathrm{ng} / \mathrm{L}$ and in others (including Paddling Pools, Water Slide and Hotel's Pool), it ranged 4.2-5.5 ng/L. The concentration of BP-3 (Fig. 2 b) in Sports Pools differed from $51.9 \mathrm{ng} / \mathrm{L}$ to $1178.6 \mathrm{ng} / \mathrm{L}$, only in one Jacuzzi it was identified at value higher than limit of quantification $\left(\mathrm{LOQ}_{\mathrm{BP}-3}=0.67 \mathrm{ng} / \mathrm{L}\right)$ and it did not occur in other pools. The concentration of BP-8 (Fig. 2 c) fluctuated considerably in ranges 53.2-86.9 $\mathrm{ng} / \mathrm{L}$ in Sports Pools, 49.9-88.9 ng/L in Jacuzzis, $51.9-226.9 \mathrm{ng} / \mathrm{L}$ in others.

The concentration level of BP-8 in this study differs a lot from the concentration range by Ekowati (Ekowati et al. 2016). The lowest value measured in this study was $49.9 \mathrm{ng} / \mathrm{L}$ while Ekowati presented $21.6 \mathrm{ng} / \mathrm{L}$ as the highest concentration of BP-8 in his work. The concentration of BP-3 in this study fluctuated considerably, which confirms the previous research by Lambropoulou et al., Giokaset al., Cuderman and Heath, Zwiener et al., Vidal et al. and Ekowati et al. In the afore-mentioned works, the concentration of BP-3 varied greatly, from $4.2 \mathrm{ng} / \mathrm{L}$ to 3300 $\mathrm{ng} / \mathrm{L}$. This paper also shows the strong variability of BP-3 concentration in the swimming pool water. The concentration of BHT in swimming pool water has never been tested before. In this study, BHT was the most common compound. It was present in 13 tested swimming pools. If present, its concentration fluctuated slightly around the mean value $4.4 \mathrm{ng} / \mathrm{L}$. The most rarely occurring compound was BP-3 (Figure 3), which was the most frequently tested Personal Care Product in previous works.

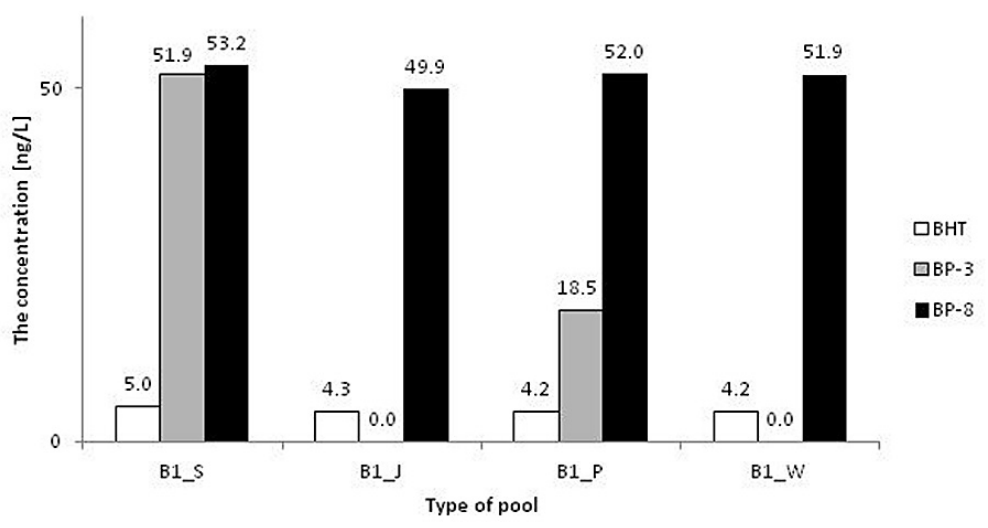

Figure 1. The concentration of BHT, BP-3 and BP-8 in different swimming pools in centre B1. 
a)

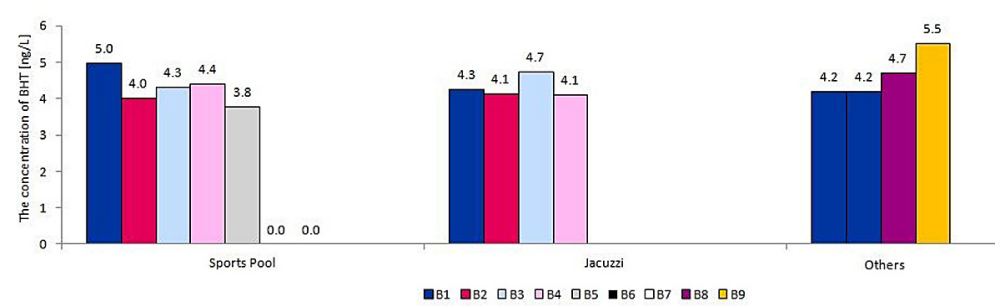

b)

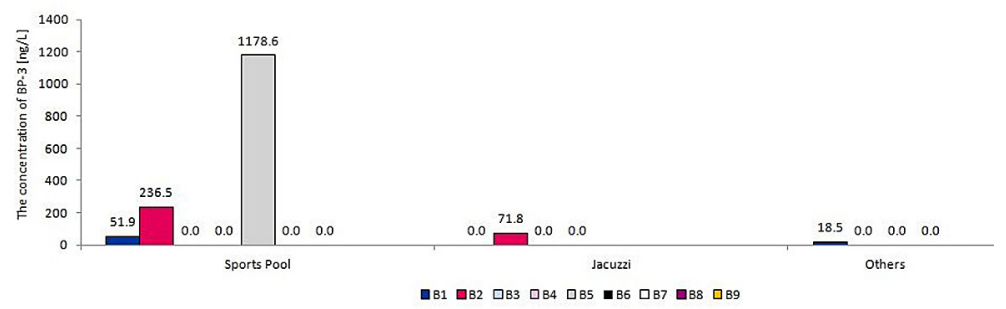

c)

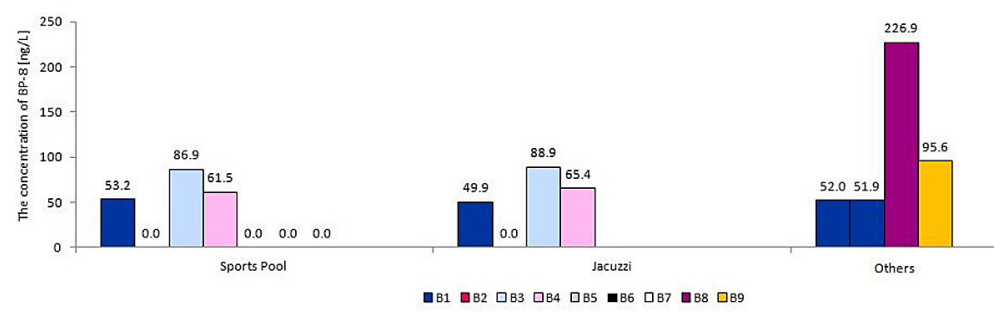

Figure 2. The concentration of selected PCPs in the same types of swimming pools in different swimming centres a) BHT, b) BP-3 c) BP-8

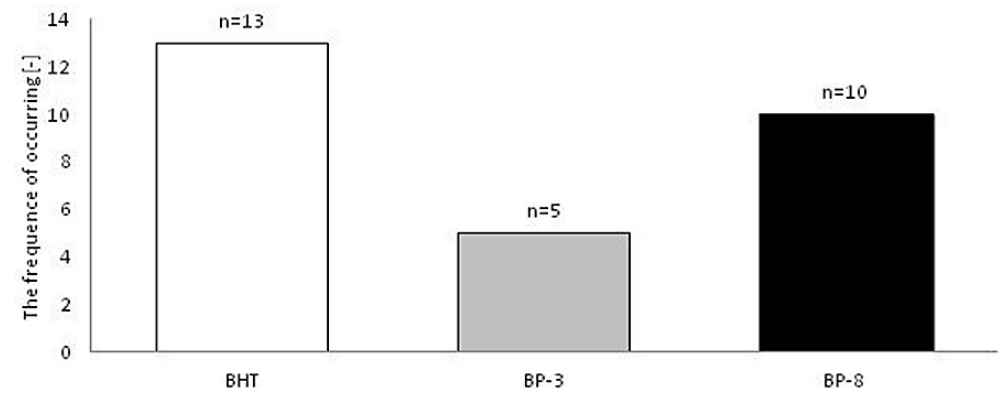

Figure 3. Occurrence of selected PCPs compounds in tested swimming pools

The Figure 4 shows frequency of appearance the different micropollutants from PCPs group in swimming pools categorized by the type of pool: Sports and Recreational (including Jacuzzi, Paddling Pool, Water Slide and Hotel's Pool).

\section{CONCLUSIONS}

It was demonstrated that the concentration level of micropollutants present in swimming pool depends on the kind of compound and the type of both swimming pool basin and the swimming pool center. Usually, the concentrations of each compound in different pool basins within a single swimming pool centre were similar. The concentrations of UV filters vary a lot in different swimming pool centers, while the concentration of antioxidant fluctuated slightly around the mean value.

The frequency of occurrence of the different micropollutants from PCPs group was higher in the recreational pools than in the sports pool. No impact of basic water quality parameters on the levels of tested pharmaceuticals has been proven in this research.

It was also concluded that the applied water treatment technology may affect the presence of the Personal Care Products in the swimming pool water. In this study, neither the type of filtra- 


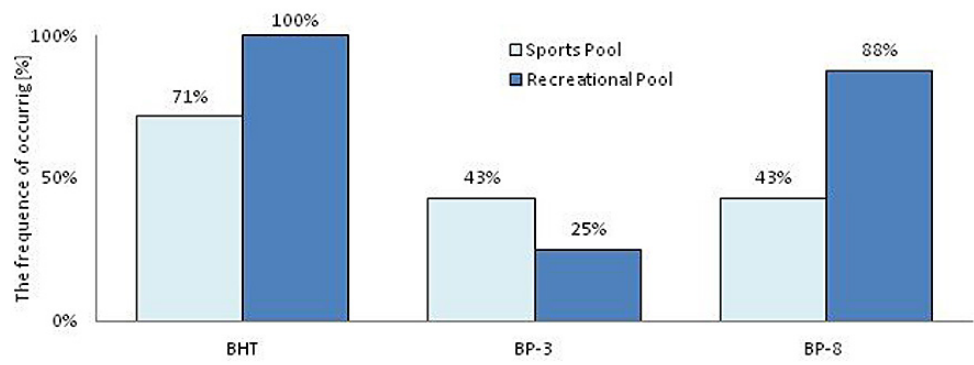

Figure 4. The frequency of occurrence the different micropollutants from PCPs group

tion bed layer nor the disinfection support technology, were analyzed. However, the high variability of concentrations of the tested PCPs suggests that some processes in pool water treatment installations may cause the decomposition or transformation of some compounds. This is particularly indicated by the absence of the tested micropollutants in pools B6 and B7.

\section{Acknowledgements}

This material is based on work supported by the Research Funds For Young Researchers awarded to the Institute of Water and Wastewater Engineering of the Silesian University of Technology (No. BKM/554/RIE-4/2017), it was also partially financed both from the resources allocated by the Ministry of Science and Higher Education in Poland (No. BK/231/RIE-4/2017) and from the funds granted by the Dean of the Faculty of Environmental Engineering and Energy of the Silesian University of Technology for the activity of the Student Scientific Club "Membrane Techniques" in the academic year 2017/2018.

\section{REFERENCES}

1. Bledzka D., Gromadzinska J., Wasowicz W. 2014. Parabens. From environmental studies to human health. Environment International, 67, 27-42.

2. Bojnarowicz H., Bartnikowska N. 2014. Sunscreen cosmetics. Part I. UV filters and their properties (in Polish). Problemy Higieny i Epidemiologii, 95(3), 596-601.

3. Boyd G.R., Reemtsma H., Grimm D.A., Mitra S. 2003. Pharmaceuticals and personal care products (PPCPs) in surface and treated waters of Louisiana, USA and Ontario, Canada. Science of The Total Environment, 311(1-3), 135-149.

4. Caliman F.A, Gavrilescu M. 2009. Pharmaceuticals, personal care products and endocrine disrupting agents in the environment - a review. CLEAN-
Soil, Air, Water, 37(4-5), 277-303.

5. Cizmas L., Sharma V.K., Gray C.M., McDonal T.J. 2015. Pharmaceuticals and personal care products in waters: occurrence, toxicity, and risk. Environmental Chemistry Letters, 13(4), 381-394.

6. Cuderman P., Heath E. 2007. Determination of UV filters and antimicrobial agents in environmental water samples. Analytical and Bioanalytical Chemistry 387, 1343-1350.

7. Díaz-Cruz M.S., Barceló D. 2009. Chemical analysis and ecotoxicological effects of organic UV absorbing compounds in aquatic ecosystems. TrAC Trends in Analytical Chemistry, 28(6), 708-717.

8. Ebele A.J., Abdallah M.A.E., Harrad S. 2017. Pharmaceuticals and personal care products (PPCPs) in the freshwater aquatic environment. Emerging Contaminants, 3, 1-16.

9. Ekowati Y., Buttiglieri G., Ferrero G., Valle-Sistac J., Diaz-Cruz M.S., Barceló D., Petrovic M., Villagrasa M., Kennedy M.D., Rodríguez-Roda I. 2016. Occurrence of pharmaceuticals and UV filters in swimming pools and spas. Environmental Science and Pollution Research International, 23, 14431-14441.

10. Giokas D.L., Sakkas V.A., Albanis T.A. 2004. Determination of residues of UV filters in natural waters by solid-phase extraction coupled to liquid chromatography-photodiode array detection and gas chromatography-mass spectrometry. Journal of Chromatography A, 1026, 289-293.

11. Giokas D.L., Sakkas V.A., Albanis T.A., Lampropoulou D.A. 2005. Determination of UV filter residues in bathing waters by liquid chromatography UV-diode array and gas chromatography-mass spectrometry after micelle mediated extractionsolvent back extraction. Journal of Chromatography A, 1077(1), 19-27.

12. Giokas D. L., Salvador A., Chisvert A. 2007. UV filters: From sunscreens to human body and the environment. TrAC Trends in Analytical Chemistry, 26(5), 360-374.

13. Golden R., Gandy J., Vollmer G. (2005) A review of the endocrine activity of parabens and implications for potential risks to human health. CRC 
Critical Reviews in Toxicology, 35(5), 435-458.

14. Kunz P.Y., Fent K. 2006. Multiple hormonal activities of UV filters and comparison of in vivo and in vitro estrogenic activity of ethyl-4-aminobenzoate in fish. Aquatic Toxicology, 79(4), 305-324.

15. Kunz P.Y., Galicia H.F., Fent K. 2006. Comparison of in vitro and in vivo estrogenic activity of UV filters in fish. Toxicological Sciences, 90(2), 349-361.

16. Lambropoulou D.A., Giokas D.L., Sakkas V.A., Albanis T.A., Karayannis M.I. 2002. Gas chromatographic determination of 2-hydroxy-4-methoxybenzophenone and octyldimethyl-p-aminobenzoic acid sunscreen agents in swimming pool and bathing waters by solidphase microextraction. Journal of Chromatography A, 967, 243-253.

17. Lempart A., Kudlek E., Dudziak M. 2017. The occurrence of micropollutants from PPCPs macro group in swimming pool water. Central European Conference ECOpole'17, 4-7 October, 2017. Abstracts, 25

18. Lempart A. Kudlek E. Dudziak M. 2018. Determination of micropollutants in water samples from swimming pool systems. Proceedings 2, 177.

19. Li W., Shi Y. Gao L., Liu1 J., \& Cai Y. 2015. Occurrence and human exposure of parabens and their chlorinated derivatives in swimming pools. Environmental Science and Pollution Research International, 22, 17987-17997.

20. Lopez-Darias J., Pino V., Meng Y., Anderson J.L., Afonso A.M., 2010. Utilization of a benzyl functionalized polymeric ionic liquid for the sensitive determination of polycyclic aromatic hydrocarbons, parabens and alkylphenols in waters using solid-phase microextraction coupled to gas chromatography-flame ionization detection. Journal of Chromatography A, 1217, 7189-7197.

21. Lowe N.J. 2006. An overview of ultraviolet radiation, sunscreens, and photo-induced dermatoses. Dermatologic Clinics, 24, 9-17.

22. Ma R., Cotton B., Lichtensteiger W., Schlumpf M. 2003. UV filters with antagonistic action at androgen receptors in the MDA-kb2 cell transcriptionalactivation assay. Toxicological Sciences, 74(1), 43-50.

23. Meeker J.D., Yang T., Ye X.Y., Calafat A.M., Hauser R. 2011. Urinary concentrations of parabens and serum hormone levels, semen quality parameters, and sperm DNA damage. Environmental Health Perspectives, 119, 252-257.

24. Morohoshi K., Yamamoto H., Kamata R., Shiraishi F., Koda T., Morita M. 2005. Estrogenic activity of 37 components of commercial sunscreen lotions evaluated by in vitro assays. Toxicology in Vitro, 19(4) 457-469.
25. Nakajima M., Kawakami T., Niino T., Takahashi Y., Onodera S. 2009. Aquatic fate of sunscreen agents octyl-4-methoxycinnamate and octyl-4- dimethylaminobenzoate in model swimming pools and the mutagenic assays of their chlorination byproducts. Journal of Health Science, 55(3), 363-372.

26. Negreira N., Canosa P., Rodríguez I., Ramil M., Rubi E., Cela R. 2008. Study of some UV filters stability in chlorinated water and identification of halogenated byproducts by gas chromatographymass spectrometry. Journal of Chromatography A, 1178(1-2), 206-214.

27. Piao C., Chen L., Wang Y. 2014. A review of the extraction and chromatographic determination methods for the analysis of parabens. Journal of Chromatography B, 969, 139-148.

28. Regueiro J., Becerril E., Garcia-Jares C., Llompart M. 2009a. Trace analysis of parabens, triclosan and related chlorophenols in water by headspace solid-phase microextraction with in situ derivatization and gas chromatography-tandem mass spectrometry. Journal of Chromatography A, 1216, 4693-4702.

29. Rodil R., Moeder M., Altenburger R., SchmittJansen M. 2009. Photostability and phytotoxicity of selected sunscreen agents and their degradation mixtures in water. Analytical and Bioanalytical Chemistry, 395 (5), 1513-1524.

30. Sakkas V., Giokas D., Lambropoulou D., Albanis T. 2003. Aqueous photolysis of the sunscreen agent octyl-dimethyl-p-aminobenzoic acid: Formation of disinfection byproducts in chlorinated swimming pool water. Journal of Chromatography A, 1016(2), 211-222.

31. Savage J.H., Matsui E.C., Wood R.A., Keet C.A. 2012. Urinary levels of triclosan and parabens are associated with aeroallergen and food sensitization. Journal of Allergy and Clinical Immunology, 130, 453-460.

32. Schlumpf M., Cotton B., Conscience M., Haller V., Steinmann B., Lichtensteiger W. 2001. In vitro and in vivo estrogenicity of UV screens. Environmental Health Perspectives, 109(3), 239-244.

33. Serpone N., Salinaro A., Emeline A.V., Horikoshi S., Hidaka H, Zhao J. 2002. An in vitro systematic spectroscopic examination of the photostabilities of a random set of commercial sunscreen lotions and their chemical UVB/UVA active agents. Photochemical \& Photobiological Sciences, 1 (12), 970-981.

34. Snyder S.A., Westerhoff P., Yoon Y., Sedlak D.L. 2004. Pharmaceuticals, Personal Care Products, and Endocrine Disruptors in Water: Implications for the Water Industry. Environmental Engineering Science, 20(5), 449-469.

35. Suppes L., Huang C.H., Lee W.N., Brockman K.J. 2017. Sources of pharmaceuticals and personal 
care products in swimming pools. Journal of Water and Health 15, 829-833.

36. Suzuki T., Kitamura S., Khota R., Sugihara K., Fujimoto N., Ohta S. 2005. Estrogenic and antiandrogenic activities of 17 benzophenone derivatives used as UV stabilizers and sunscreens. Toxicology and Applied Pharmacology, 203(1), 9-17.

37. Tavares R.S., Martins F.C., Oliveira P.J., Ramalho-Santos J., Peixoto F.P. 2009. Parabens in male infertility-Is there a mitochondrial connection? Reproductive Toxicology 27, 1-7.

38. Terasaki M., Makino M. 2008. Determination of chlorinated by-products of parabens in swimming pool water. International Journal of Environmental Analytical Chemistry, 88, 911-922.

39. Terasaki M., Makino M., Tatarazako N. 2009. Acute toxicity of parabens and their chlorinated by-products with Daphnia magna and Vibrio fischeri bioassays. Journal of Applied Toxicology, 29(3), 242-247.

40. Terasaki M., Takemura Y., Makino M. 2012 Paraben-chlorinated derivatives in river waters. Environmental Chemistry Letters, 10, 401-406.

41. Vidal L., Chisvert A., Canals A., Salvador A. 2010.
Ionic liquid-based single-drop microextraction followed by liquid chromatographyultraviolet spectrophotometry detection to determine typical UV filters in surface water samples. Talanta, 81, 549-555.

42. Virkutyte J., Al-Abed S.R., Dionysiou D.D. 2012. Depletion of the protective aluminum hydroxide coating in TiO2-based sunscreens by swimming pool water ingredients. Chemical Engineering Journal, 191, 95-103.

43. Westerhoff P., Yoon Y., Snyder S., Wert E. 2005. Fate of endocrinedisruptor, pharmaceutical, and personal care product chemicals during simulated drinking water treatment processes. Environmental Science and Technology, 39, 6649-6663.

44. Yang Y., Ok Y.S., Kim K.H., Kwon E.E., Tsang Y.F. 2017. Occurrences and removal of pharmaceuticals and personal care products (PPCPs) in drinking water and water/sewage treatment plants: A review. Science of The Total Environment, 596-596, 303-320.

45. Zwiener C., Richardson S.D., De Marini D.M., Grummt T., Glauner T., Frimmel F.H. 2007. Drowning in disinfection byproducts? Assessing swimming pool water. Environmental Science and Technology, 41, 363-372. 